\title{
Nagyvállalatok pénzügyi teljesítményének és társadalmi felelősségvállalásának összefüggései Magyarországon
}

\begin{abstract}
A tanulmány a kelet-közép-európai országokban müködő nagyvállalatok fenntarthatósági tevékenysége és pénzügyi teljesítménye közötti összefüggéseket elemzi 95 magyar nagyvállalat példáján. Az alkalmazott módszertan kétmintás Wilcoxonpróba, amely a fenntarthatósági beszámolók és a fenntartható müködéssel kapcsolatban álló ISO 9001, ISO 14001 és az OHSAS 18001 szabványok megléte szerint vizsgálja a vállalatok 2014. és 2015. évi jövedelmezőségi adatait. Csak a tőzsdén nem jegyzett vállalatok esetében mutatható ki szignifikáns kapcsolat. Az eredmények alapján az ISO 9001 tanúsítvánnyal rendelkező cégek eszközarányos megtérülése (ROA), valamint az adózás utáni bázison számított tőkearányos megtérülése (ROE) szignifikánsan magasabb, mint a szabvánnyal nem rendelkező cégeké. Az ISO 14001 vagy az OHSAS 18001 szabványok legalább egyikének megléte szintén szignifikáns pozitív kapcsolatban áll az eszközarányos megtérüléssel (ROA). A fenntarthatósági beszámoló közzététele nem gyakorol érdemi befolyást a jövedelmezőségre. A magyarországi nagyvállalatok fenntarthatósági teljesítménye elmarad a lengyel és a cseh cégekétől. A hazai nagyvállalatok fenntarthatósági tevékenysége jelenleg a szabványok bevezetésének a fázisában van.* Journal of Economic Literature (JEL) kód: M14, Q01, G32, C58.
\end{abstract}

A fenntarthatóság egyre fontosabb szerepet kap a vállalkozások mindennapjaiban. Amellett, hogy a 2007-ben kezdődött globális pénzügyi válság utáni időszak legnagyobb nyertesei közé az innovatív, társadalmilag felelősen müködő vállalatok tartoznak, valamennyi vállalat esetén megfigyelhetö, hogy az érintettek egyre szélesebb köre (befektetők, munkavállalók, szabályozók, nem kormányzati szervezetek) vár el a

* A szerző ezúton is köszönetét fejezi ki Vakhal Péternek az elemzés módszertanát illető konstruktív észrevételeiért. A tanulmány elkészültét az EFOP-3.6.1-16-2016-00012. sz. Intelligens szakosodást szolgáló intézményi fejlesztések - Innovatív megoldásokkal Zala megye $\mathrm{K}+\mathrm{F}+\mathrm{I}$ tevékenysége hatékonyságának növeléséért című program támogatta.

Szennay Áron a BGE PSZK oktatója, a SZE RGDI doktorandusza. A tanulmány az MTA-BGE Makrogazdasági fenntarthatósági kutatócsoport mint munkahely keretében, az MTA Támogatott Kutatócsoportok Irodájának támogatásával készült. A szerző a kutatócsoport tagja.

A kézirat első változata 2017. szeptember 15-én érkezett szerkesztőségünkbe.

DOI: http://dx.doi.org/10.18414/KSZ.2018.12.1281 
vállalatokról nem pénzügyi információkat (Farkas-Szigeti [2011]). A vállalatok társadalmi felelősségvállalása (corporate social responsibility, CSR) az egyre szélesebb körü alkalmazás ellenére jelenleg a diszciplinarizálódás stádiumában van, definíciója nem teljesen letisztult, a felelős vállalati magatartás elemeit és azok hatásmechanizmusait nem vagy csak részben általánosították (Braun [2013]).

A vállalatok társadalmi felelősségvállalásának koncepciója az Egyesült Államokban született meg, a tapasztalatok szerint azonban a vállalatok tevékenységük társadalmi, gazdasági és környezeti hatásaiért való felelősségvállalása a fejlett nyugati világ egészében követelménnyé vált. Ez elsősorban a „hazai” hatásokra vonatkozik, az országhatáron túlra terjedő környezeti hatásokért érzett felelősség nagysága a távolság növekedésével csökken.

A világ többi részén a vállalatok társadalmi felelösségvállalása jelenleg még csak kibontakozóban van, a szereplők inkább csak követő magatartást tanúsítanak, mintsem proaktívan tevékenykednének. Ez feltehetően abból következik, hogy e társadalmak számára jelenleg egységnyi gazdaságijövedelem-növekmény nagyobb értéket jelent, mint egységnyi növekmény a társadalmi vagy környezeti teljesítményben, és/ vagy nem épültek ki azok az intézmények, amelyek a felelős magatartást kikényszeríthetnék (Dhaliwal és szerzötársai [2012]).

Az Európai Unió kelet-közép-európai tagállamai esetén a helyzet bonyolultabb, ugyanis legalább három hatás érvényesül egyidejüleg: 1. a „CSR-örökség”, vagyis a szocialista rendszer állami vállalatainak társadalmi tevékenysége (üdülők, óvodák, orvosi rendelők stb.) (Kerekes-Wetzker [2007]), 2. a nyugati világcégek helyi leányvállalatai esetén gyakran elvárásként jelenik meg az anyaországban megszokott felelősségvállalás - mint legjobb gyakorlat - gyors átvétele, amit a szereplők sokszor szkeptikusan fogadnak, rendszeridegennek tekintenek (Radácsi [2011]), 3. az EU-s jogalkotás, környezetvédelmi célok és támogatási programok külső követelményként jelentkeznek, és nem feltétlenül tükrözik a helyi közösségek értékrendjét.

Az elmúlt évtizedben több tanulmány is vizsgálta a kelet-közép-európai vállalatok CSR-tevékenységét, valamint annak a pénzügyi teljesítményre gyakorolt hatását. A tanulmányok eredménye eltérö: míg Earnhart-Lizal [2007] a cseh, PrzychodzenPrzychodzen [2015] pedig a lengyel és a magyar tőzsdei cégek adatait vizsgálva jutott arra, hogy a CSR-tevékenység valamely indikátora pozitívan hat a jövedelmezőségre, addig Pintea és szerzőtársai [2014] a bukaresti tőzsdén jegyzett vállalatokat vizsgálva nem talált szignifikáns kapcsolatot a két teljesítmény között. Specifikusan magyar vállalkozásokra vonatkozó kutatás eddig nem ismert. Jelen tanulmányban 95, Magyarországon mủködő nagyvállalat pénzügyi és nem pénzügyi teljesítményére vonatkozó adatait elemezve vizsgáljuk a két teljesítmény közötti kapcsolatot.1

A tanulmány először áttekinti a kutatáshoz kapcsolódó legfontosabb hazai és nemzetközi szakirodalmat, majd bemutatja az alkalmazott mintát és a módszertant, továbbá magát az elemzést és annak eredményeit. Végül összefoglalja a föbb következtetéseket és a kutatás további lehetséges irányait.

\footnotetext{
${ }^{1}$ A tanulmányban nem pénzügyi teljesítményen a környezeti, illetve a társadalmi teljesítményt értjük.
} 


\section{Elméleti keretek}

\section{A felelös müködés és annak jövedelmezöségi hatásai}

Jelen tanulmány célja a magyarországi nagyvállalatok jövedelmezősége és CSRtevékenysége közötti kapcsolat elemzése, így nem vállalkozunk a CSR-diskurzusok részletekbe menő tárgyalására, csupán a témához kapcsolódó legfontosabb elméleti keretrendszereket mutatjuk be.

A vállalati társadalmi felelősségvállalás az Európai Bizottság definíciója szerint olyan üzleti koncepció, „melynek értelmében a vállalatok - önkéntes alapon - társadalmi és környezetvédelmi szempontokat érvényesítenek üzleti tevékenységük során és partnereikkel fenntartott kapcsolataikban" (EB [2011] 4. o.). A meghatározás kitér arra, hogy a CSR a „törvényi kötelezettségeiken túlmenő felelősségre vonatkozik” (uo.).

Carroll [1991] a vállalatok társadalmi felelösségvállalását tágabb kategóriaként, a vállalat gazdasági, jogi, etikai és filantróp (diszkrecionális) felelősségvállalásaként határozza meg (Carroll [1979], idézi Carroll [1991]). Ennek a négy dimenziónak egymásra rétegződését szemlélteti a CSR-piramis, amelynek két alsó szintje (a gazdasági, illetve a jogi felelősségvállalás) a tulajdonosi elvárásokat, valamint az állam kötelező érvényű (jogi) szabályozását foglalja magában. A piramis harmadik szintjét az etikai dimenzió alkotja, amely a társadalmi normáknak, elvárásoknak való megfelelést takarja, míg a negyedik szint a filantróp felelősségvállalás, amely a saját meggyőződésböl végzett tevékenységeket foglalja magában. Fontos kiemelni, hogy ugyan Friedman [1970] híres cikkében azt állítja, hogy „a vállalat egyetlen felelőssége a profit maximalizálása”, elismeri, hogy „a vállalati müködés során be kell tartani a társadalom alapvető szabályait, legyenek azok törvényi vagy etikai természetűek”. Ez azt jelenti, hogy a friedmani ortodoxia a CSR-piramis alsó három szintjét legitimnek, vagyis a tulajdonosok érdekeivel azonosnak ismeri el (Caroll [1991]).

A vállalati társadalmi felelősségvállalás pénzügyi teljesítményre, végső soron a tulajdonosi értékre gyakorolt hatása ennek ellenére a mai napig vitatott témakör. A két tényező közötti kapcsolat háromféle lehet: 1 . a CSR nem gyakorol szignifikáns hatást a pénzügyi teljesítményre, vagyis, ha a menedzsment a CSR-tevékenység mellett dönt, akkor azzal a tulajdonosi értéket nem befolyásolja; 2. a CSR szignifikáns és negatív kapcsolatban áll a pénzügyi teljesítménnyel, azaz csökkenti a tulajdonosok vagyonát; 3. a CSR és a pénzügyi teljesítmény között pozitív szignifikáns kapcsolat áll fenn, tehát a CSR-tevékenység értéket teremt. Jelen tanulmány e hipotéziseket vizsgálja a magyarországi nagyvállalatok esetében.

Kétségtelen, hogy a felelős működés nemritkán költséges beruházásokkal (például szüröberendezések telepítése) és/vagy a müködési költségek növekedésével (például egyenlő bérek, drágábban üzemeltethetö technológia) jár.

A felmerülő költségek mellett azonban a felelősségvállaláshoz számos közvetlen, illetve közvetett pénzügyi elöny társítható, amelyek a többletköltségeket ellensúlyozhatják. Ilyen hatások lehetnek például a következők:

- a nagyobb anyag- és energiahatékonyság során elérhetö költségcsökkenés (Tsoutsoura [2004], Radácsi [2011]); 
- a környezeti problémák megoldása által az energia, valamint a hulladékkezelés költségeinek csökkenése (Kerekes-Wetzker [2007]);

- új innovatív és környezetbarát(abb) termékek, illetve szolgáltatások (SzékelyKnirsch [2005]);

- jobb reputáció, nagyobb értékü brand (Tsoutsoura [2004], Radácsi [2011], Kerekes-Wetzker [2007]);

- a munkahelyi balesetek, környezetkárosítással járó események kisebb kockázata (Škare -Golja [2012], Brine és szerzőtársai [2007], idézi Özçelik és szerzötársai [2014], Tsoutsoura [2004]);

- a helyi közösségektől kapott „müködési engedély” (Székely-Knirsch [2005]);

- alacsonyabb kockázati prémium (Ng-Rezaee [2015], Cheng és szerzötársai [2011], idézi Kuti [2014], Orlitzky-Benjamin [2011], idézi Kuti [2014]);

- lojálisabb, elkötelezettebb munkavállalók (Tsoutsoura [2004]).

Több szerző amellett érvelt, hogy a vállalati társadalmi felelősségvállalás a jövedelmezőségre - vagyis a bevételekre és/vagy költségekre - gyakorolt hatás mellett a kockázati prémium által is befolyásolhatja a vállalati értéket. A kockázati prémium a szakirodalom szerint két csatornán keresztül jelenhet meg. Egyrészt a nagyobb transzparencia folytán mérséklődnek az ügynöki költségek, így a tulajdonosok a befektetésükhöz kisebb kockázatot társítanak (Cheng és szerzőtársai [2011], idézi Kuti [2014], Orlitzky-Benjamin [2011], idézi Kuti [2014]). A feltevést Ng-Rezaee [2015] 1991 és 2013 közötti vállalati adatokkal empirikus módon is igazolta.

Másrészt a befektetői piacon egyre jelentősebb részt képviselnek a társadalmilag felelős befektetők (socially responsible investor, SRI), amelyek több módszerrel is arra ösztönzik a vállalatokat, hogy tevékenységük során társadalmi szempontokat is mérlegeljenek. A nyomásgyakorlás jellemzően a következő formákat ölti: 1. negatív diszkrimináció, vagyis cégek vagy szektorok mellőzése; 2. pozitív diszkrimináció; 3. beavatkozás (az igazgatótanácsba való delegálás a nem támogatott gyakorlatok megváltoztatása céljából); 4. tulajdonosi aktivizmus (protesztszavazatok a közgyülésen) (Székely-Knirsch [2005]). Tekintettel arra, hogy a felelösen müködő cégek nagyobb befektetői kört (mind a társadalmilag felelös, mind a felelös müködéssel kapcsolatban közömbös befektetöket) érnek el, ezért ceteris paribus ezen cégek tőkeköltsége és érzékelt kockázata várhatóan alacsonyabb (Ghoul és szerzőtársai [2011]). Ehhez hasonló logika alapján Heinkel és szerzötársai [2001] (idézi Ghoul és szerzőtársai [2011]) egyensúlyi modellje arra a következtetésre jut, hogy a kevésbé kiterjedt tulajdonosi kör esetében kisebb a lehetőség a kockázatok diverzifikációjára, ezáltal magasabb a várható tőkeköltség.

A pénzügyi és nem pénzügyi teljesítmény közötti kapcsolat empirikus vizsgálatai

Az elméleti diskurzus mellett a szakirodalomban számos példa található a vállalati pénzügyi és nem pénzügyi teljesítmény közötti kapcsolat empirikus elemzésére. A kutatások túlnyomórészt nagy, nemzetközileg is aktív vállalkozásokra 
irányultak. Stanwick-Stanwick [1998] az Egyesült Államok 500 legnagyobb károsanyag-kibocsátó és a Fortune 500 listán is szereplő vállalatainak 1987 és 1992 közötti adatait vizsgálva jutott arra a következtetésre, hogy a kisebb károsanyagkibocsátású vállalatoknak a jövedelmezősége szignifikánsan magasabb. Tsoutsoura [2004] az S\&P 500 indexbe tartozó vállalatok 1996 és 2000 közötti mutatóinak elemzése során bizonyította, hogy a Kinder Lydenberg Domini (KLD) fenntarthatósági értékelése és a pénzügyi teljesítmény között szignifikáns pozitív kapcsolat áll fenn. ${ }^{2}$ Škare-Golja [2012] 45, a Dow Jones Sustainable World Indexben (DJSWI) szereplö és 45, az indexben nem szereplő vállalat 2006 és 2008 közötti adatait elemezve jutott arra a következtetésre, hogy a fenntarthatósági indexben szereplő vállalatok pénzügyi teljesítménye magasabb volt, mint az indexben nem szereplöké. Blasi és szerzőtársai [2018] 998 amerikai vállalat 2003 és 2015 közötti megtérülési mutatói és a KLD-értékelés közötti kapcsolatot vizsgálta. A kutatásban a szerzők nemcsak számviteli típusú megtérülési mutatókat, hanem a befektetők értékítéletét is tartalmazó, piaci típusú jövedelmezőségi mutatókat is vizsgáltak, emellett a KLD-értékelés hét dimenzióját egyedileg is vizsgálták. Az eredmények alapján a piaci típusú mutatók (a felső vezetésben való nemek közötti különbségek kivételével) a vállalati társadalmi felelősségvállalás valamennyi dimenziójával pozitív kapcsolatban állnak. A számviteli típusú mutatók közül a tőkearányos megtérülés (return on equity, ROE) és a felső vezetésben a nemek közötti különbségek között szignifikáns pozitív, míg a befektetésarányos megtérülés (return on investments, ROI) a felelősségvállalással negatív kapcsolatban áll.

Országspecifikus elemzésekre is sor került. Przychodzen-Przychodzen [2015] 439 lengyel és 13 magyar tőzsdei cég 2006 és 2013 közötti adatai alapján bizonyította, hogy az ökoinnovatív cégek eszközarányos megtérülése (return on assets, ROA) szignifikánsan magasabb, mint a nem ökoinnovatív cégeké. Pintea és szerzőtársai [2014] 2005 és 2010 közötti bukaresti tőzsdei adatok alapján jutott arra a következtetésre, hogy nincs kapcsolat a pénzügyi teljesítményés a vállalatok széndioxid- $\left(\mathrm{CO}_{2}\right)$ kibocsátása között (a jövedelmezőség mérésére a szerzők a ROA és a ROE mutatókat alkalmazták). Özçelik és szerzőtársai [2014] 81, az isztambuli tőzsdén jegyzett vállalkozás 2010 és 2013 közötti adatai alapján állapította meg, hogy a fenntarthatósági beszámoló közzététele és a pénzügyi teljesítmény között nincs szignifikáns kapcsolat, azonban a nagyobb eszközállományú cégek nagyobb valószínüséggel készítenek fenntarthatósági beszámolót. Cseh cégek elemzése alapján Earnhart-Lizal [2007] arra a következtetésre jutott, hogy a környezeti teljesítmény a költségeket a bevételeknél nagyobb mértékben csökkenti, így járulva hozzá a jövedelmezőség növeléséhez.

Célzottan a magyarországi cégek pénzügyi és nem pénzügyi teljesítménye közötti vizsgálat eddig nem készült, azonban a hazai vállalatok fenntarthatósági tevékenységének több szempontját is vizsgálták. A KPMG [2010] felmérése szerint

\footnotetext{
${ }^{2} \mathrm{Az}$ eredmények alapján a legerősebb kapcsolat az eszközarányos megtérülés (return on assets, $R O A)(p=0,001)$ és az árbevétel-arányos jövedelmezőség (return on sales, $R O S)(p=0,05)$ között állapítható meg. A tőkearányos megtérülés (return on equity, $R O E$ ) csak $p=0,1$ mellett tekinthető szignifikáns magyarázó változónak.
} 
Magyarország 100 legnagyobb vállalatának csupán harmada számolt be nem pénzügyi teljesítményéről, a beszámolók fele különálló jelentésben, harmada integrált jelentésben jelent meg, míg a fennmaradók mindkét típust használták. A WWF kutatása a Figyelő 2015-ös listáján szereplő 50 legnagyobb árbevételü cég, valamint az öt-öt legnagyobb bank és biztosító elemzése alapján állapította meg, hogy a cégek mintegy ötödében a felső vezetők elkötelezettek a klímaváltozással kapcsolatban, valamint a vizsgált cégek tizede rendelkezik számszerü, évhez kötött $\mathrm{CO}_{2}$ kibocsátási céllal (Csizmadia-Vaszkó [2016]).

A kis- és középvállalati szektor elemzése az irodalomban meglehetősen ritka, ez alól kivétel Tomšič és szerzőtársai [2015] szlovén, illetve Witjes és szerzőtársai [2017] holland cégek megkérdezésén alapuló tanulmánya. Ezekben az esetekben az adatok rendelkezésre állásától függően elsősorban kvalitatív elemzések történtek.

Akad példa a makroszintű elemzésekre is: Li és szerzőtársai [2016] a kínai tőzsdén jegyzett 681 cég 2005 és 2014 közötti társadalmi felelösségvállalási teljesítménye és a gazdasági fejlődés különböző mutatói ${ }^{3}$ közötti kapcsolatot vizsgálva kimutatta, hogy szignifikáns pozitív kapcsolat van a nemzet gazdasági fejlődése és a társadalmi felelősségvállalás szintje között.

\section{Az alkalmazott minta és módszertan}

A magyarországi vállalatok pénzügyi és nem pénzügyi teljesítménye közötti kapcsolat elemzését magyar nagyvállalatok mintáján végeztük el. A kis- és középvállalati szektor mellőzése illeszkedik a laza költségvetés elméletéhez (slack resource theory), amely szerint a fenntarthatósággal kapcsolatos tevékenységek elsősorban a nagyvállalatoknál figyelhetők meg, ugyanis azok rendelkeznek a szükséges stratégiai pénzügyi tartalékokkal (Tsoutsoura [2004]). Az elmélet más oldalról is alátámasztható, ugyanis az akár globális szinten is müködő nagyvállalatok tevékenysége rendszerint sokkal komplexebb, ezáltal legitim társadalmi igény a cégek transzparensebbé tétele (Szennay [2016]). A gyakran nemzetgazdaság-méretü teljesítményt produkáló transznacionális cégek fokozott transzparenciáját, valamint az erősebb politikai és morális bevonódását hirdeti a CSR-diskurzus egy újabb ága is, a vállalatok újrapolitizálódása (Géring [2015]).

A mintában szereplő vállalatok pénzügyi adatainak forrása a Bureau van Dijk (BvD) Amadeus-adatbázisban ${ }^{4}$ szereplő, 2014. és 2015. évi beszámolók. A pénzügyi teljesítmény mérése az adott évre vonatkozó, adózás előtti bázison számított ROA-, ${ }^{5}$ valamint az adózás előttii, ${ }^{6}$ illetve az adózás utáni bázison számított ${ }^{7}$ ROE-mutatókkal történt.

\footnotetext{
${ }^{3}$ A négy vizsgált makrogazdasági mutató a gazdasági hozzáadott érték (economic value added, $E V A)$, a GDP növekedési rátája, az állóeszközbe történő beruházás növekedése és az egy före jutó rendelkezésre álló jövedelem növekedése volt.

${ }^{4} \mathrm{https} / /$ amadeus.bvdinfo.com/version-2017630/home.serv?product=amadeusneo.

${ }^{5}$ Eszközarányos jövedelmezőség $=$ (adózás előtti eredmény/összes eszköz) $\times 100$ (BvD Amadeus).

${ }^{6}$ Sajáttőke-arányos jövedelmezőség $=$ (adózás előtti eredmény/saját tőke) $\times 100$ (uo.).

${ }^{7}$ Sajáttőke-arányos jövedelmezőség $=($ adózás utáni eredmény/saját tőke $) \times 100$ (uo.).
} 
Bár a mutatók többféleképpen, akár a vizsgálat tárgyához az alkalmazottnál jobban illeszkedő módon is kiszámíthatók, az eredmények reprodukálhatósága érdekében az elemzésekben a BvD Amadeus által számított értékek szerepelnek. A pénzügyi adatok lekérdezése 2018. március 2-án történt meg.

A minta két részre osztható: a Budapesti Értéktőzsdén (BÉT) jegyzett, ${ }^{8}$ valamint a tőzsdén nem jegyzett vállalatokra. A BÉT-en jegyzett, prémiumkategóriás részvények esetén a felvétel csaknem teljes körü. ${ }^{9}$ A standard kategóriában célunk az volt, hogy megközelítőleg a vállalatok felét megfigyeljük, s egyszerü véletlen mintavétellel kilenc cég került kiválasztásra, ami 47 százalékos kiválasztási aránynak felel meg. A tőzsdén nem jegyzett cégek mintája 75 - Magyarországon aktív, az utóbbi években beszámolót leadott - nagyvállalat véletlenszerü, de a vállalkozások székhelyének település régiója szerinti arányos kiválasztásából állt elő. A mintavétel során először megállapítottuk, hogy az egyes régiókból hány vállalat kerülhet a mintába, ${ }^{10}$ majd a régiónként véletlenszerü sorrendbe rendezett cégek listájáról a sorrendben elöl szereplő cégek közül ennek megfelelő számú vállalatot vontuk be a mintába.

A fenntartható müködést a fenntarthatósági beszámoló közzététele, valamint az alkalmazott, fenntarthatósággal kapcsolatos tanúsítványok megléte indikálja. A modellben e változók kategóriaváltozóként szerepelnek.

A fenntarthatósági beszámoló közzététele a fenntartható vállalati működés egyik bevett indikátora. Az egy országra vonatkozó elemzések között Özçelik és szerzőtársai [2014] az isztambuli, Angelia-Suryaningsih [2015] az indonéz tőzsdén jegyzett cégek, míg Mathuva-Kiweu [2016] a kenyai takarékszövetkezetek pénzügyi és nem pénzügyi teljesítménye közötti kapcsolat elemzése során használta a fenntartható müködés mutatójaként a nem pénzügyi beszámolót. Margolis és szerzőtársai [2009] metaelemzése során 17 olyan kéziratot vizsgált, amelyben a fenntartható működést a releváns beszámoló közzététele indikálta.

A fenntarthatósági beszámolókkal kapcsolatos adatok elsődleges forrása - Dhaliwal és szerzőtársai [2012]-höz hasonlóan - a Corporate Register. ${ }^{11}$ Tekintettel arra, hogy a magyar cégek számára a Corporate Register nem feltétlenül ismert, a mintánkban szereplő többi cég weboldalain megtalálható beszámolókat is figyelembe vettük ${ }^{12}$ abban az esetben, ha a cég a 2011 és 2015 közötti időszakban legalább két fenntarthatósági beszámolót tett közzé. Az elemzésben más, a fenti forrásokban nem fellelhetö beszámoló nem szerepel, ugyanis feltételezhető, hogy ha a vállalkozás a beszámolóját sem a

${ }^{8}$ A lekérdezés dátuma 2017. július 20.

${ }^{9}$ A hiányosságot az okozza, hogy az Amadeus-adatbázisban a pénzügyi vállalatok, így például a bankok adatai nem szerepelnek. Az adatok konzisztenciáját biztosítandó, ezeket a vállalatokat kihagytuk a mintából.

${ }^{10}$ A lekérdezéskor az adatbázisban 3821 nagyvállalat adata szerepelt. Ebből a nyugat-magyarországi településen székhellyel rendelkezők aránya 8 százalék (312 darab) volt. Ennek megfelelően a 75 céget tartalmazó mintában (kerekítés mellett) a nyugat-magyarországi cégekre vonatkozó kvóta 6 darab.

${ }^{11}$ A Corporate Register több mint 14 ezer szervezet fenntarthatósági beszámolóját rögzítette. Magyarországról 63 vállalkozás töltött fel egy vagy több üzleti évre vonatkozó beszámolót. Éves bontásban azonban a trend csökkenő. A hazai cégek közül míg 2012-ben 28, addig 2016-ban csupán 19 tett közzé beszámolót (http://www.corporateregister.com).

${ }^{12} \mathrm{Az}$ adatfelvétel 2017. július 24. és 28. között történt. 
saját weboldalán, sem egy ismert szakosított adatbázisban nem teszik közzé, akkor az nem teljesíti a funkcióját, vagyis a müködéssel kapcsolatos többlet (fenntarthatósági) információk közzétételét.

A fenntarthatósági müködést a vállalatok különböző szabványok szerinti tanúsítványai a fenntarthatósági beszámolókhoz hasonlóan indikálhatják. A fenntarthatósághoz kapcsolódó szabványnak tekinthető többek között az EMAS, az ISO 9001, az ISO 14001 vagy az OHSAS 18000 (Siew [2015]). Crifo és szerzőtársai [2016] a környezeti dimenzióban felelösen viselkedőnek tekintette azokat a cégeket, amelyek valamely szabvány, például az ökocímke, a fair trade vagy az ISO 14001 szerinti tanúsítvánnyal rendelkeznek. Witjes és szerzötársai [2017] a holland kis- és középvállalatoknál három szabvány, az ISO 9001, az ISO 14001 és az OHSAS $18001^{13}$ alkalmazását vizsgálta.

Jelen tanulmányban a fenntartható működéshez Witjes és szerzötársai [2017] munkájához hasonlóan az ISO 9001, az ISO 14001, valamint az OHSAS 18001 szabványokat társítjuk. Az MSZ EN ISO 9001:2015 jelzetü (továbbiakban: ISO 9001) szabvány alkalmazása esetén a szervezetnek bizonyítani kell, hogy képes folyamatosan a vevői elvárásoknak és a jogszabályi és egyéb szabályozói követelményeknek megfelelö terméket és/vagy szolgáltatást nyújtani, valamint a bevezetett minőségbiztosítási rendszer eredményes használatával célja a vevői elégedettség növelése. ${ }^{14}$ Az MSZ EN ISO 14001:2015 jelzetű (továbbiakban: ISO 14001) szabvány a környezeti hatások szisztematikus kezelését szolgáló információs rendszer kiépítését támogatja. ${ }^{15}$ Az OHSAS 18001 szabvány célja olyan munkabiztonsági és egészségvédelmi irányítási rendszer kiépítése, amely elfogadott költségszint mellett csökkenti elfogadható szintre a kockázatokat. ${ }^{16}$ A szabványok meglétét a vállalatok saját weboldalain szereplő információk alapján állapítottuk meg. ${ }^{17}$ Feltételezzük, hogy ha a szabványokkal egy vállalat rendelkezik, akkor alkalmazza is azokat. Erröl a rendszeres auditok gondoskodnak.

A hipotézisvizsgálat során fenntarthatónak tekintettük azt a vállalatot, mely valamely fenntarthatósági indikátor (fenntarthatósági beszámoló, ISO 9001, ISO 14001 vagy OHSAS 18001) szerint fenntarthatónak minősül. A részletes elemzés céljából az indikátort négy mutatóra bontva külön is elemeztük: 1. fenntarthatósági beszámoló közzététele, 2. ISO 9001 szerinti tanúsítvány megléte, 3. ISO 9001 és ISO 14001 vagy OHSAS 18001 szerinti tanúsítványok megléte, 4. ISO 14001 vagy OHSAS 18001 szerinti tanúsítvány(ok) megléte.

Tekintettel arra, hogy a jövedelmezőségi mutatók eloszlása nem követi a normális eloszlást (1. táblázat), az elemzés módszere a kétmintás $t$-próba nemparaméteres párja, a kétmintás Wilcoxon-próba.

\footnotetext{
${ }^{13}$ Occupational Health and Safety Assessment Series (OHSAS) - Munkahelyi Egészségvédelmi és Biztonsági Értékelési Sorozat.

${ }^{14}$ Magyar Szabványügyi Testület (http://www.mszt.hu/web/guest/ingyenes-szabvanylista).

${ }^{15}$ Magyar Szabványügyi Testület (http://www.mszt.hu/web/guest/ingyenes-szabvanylista).

${ }^{16}$ ÉMI-TÜV SÜD (https://www.emi-tuv.hu/hu-hu/tevekenysegek/audit-es-rendszer-tanusitas/ mebir-bs-ohsas-18001-munkabiztonsag).

${ }^{17} \mathrm{Az}$ adatfelvételre ez esetben is 2017. július 24. és 28. között került sor.
} 
1. táblázat

A megtérülési mutatók normális eloszlásának tesztelése

\begin{tabular}{lcccccccc}
\hline Mutató & \multicolumn{3}{c}{ Kolmogorov-Smirnov } & & \multicolumn{3}{c}{ Shapiro-Wilk } \\
\cline { 2 - 3 } & $\begin{array}{c}\text { próbafüggvény } \\
\text { értéke }\end{array}$ & $\begin{array}{c}\text { szigni- } \\
\text { fikancia }\end{array}$ & $p$-érték & & $\begin{array}{c}\text { próbafüggvény } \\
\text { értéke }\end{array}$ & $\begin{array}{c}\text { szigni- } \\
\text { fikancia }\end{array}$ & $p$-érték \\
\hline $\begin{array}{l}\text { ROE (adózás } \\
\text { elött, százalék) }\end{array}$ & 0,252 & 183 & 0,000 & & 0,472 & 183 & 0,000 \\
$\begin{array}{l}\text { ROA(adózás } \\
\text { előtt, százalék) }\end{array}$ & 0,162 & 183 & 0,000 & & 0,826 & 183 & 0,000 \\
$\begin{array}{l}\text { ROE(adózás } \\
\text { után, százalék) }\end{array}$ & 0,242 & 183 & 0,000 & & 0,460 & 183 & 0,000 \\
\hline
\end{tabular}

Forrás: saját szerkesztés.

A hipotézisvizsgálat során először kétszélü próbát végeztünk annak megállapítására, hogy azonosnak tekinthetö-e a fenntartható és a nem fenntartható cégek jövedelmezőségi mutatóinak mediánja. A kapcsolat irányának megállapításához egyszélü próbát végeztünk, amelynek alternatív hipotézise, hogy az adott szempont szerint nem fenntartható (például nem rendelkezik ISO 9001 szerinti tanúsítvánnyal), valamint a fenntarthatónak tekinthető (vagyis ez esetben az ISO 9001 szerinti tanúsítvánnyal rendelkező) vállalkozások megtérülési mutatói közötti különbség negatív. Az alternatív hipotézis elfogadása esetén igazolható, hogy a fenntarthatóan müködő cégek megtérülése a nem fenntarthatóan müködőknél szignifikánsan magasabb. Valamennyi elemzés végrehajtása az $R$ statisztikai szoftverrel történt.

\section{Eredmények, következtetések}

\section{Leíró statisztikák}

A tőzsdén nem jegyzett cégek legnagyobb része feldolgozóipari tevékenységet folytat (32 százalék), de jellemző még a kereskedelem (17,3 százalék), valamint az ingatlanügyletekkel kapcsolatos tevékenység is (12 százalék). A tőzsdei cégek esetében szintén a feldolgozóipari tevékenység a legjellemzőbb (20 százalék), azonban hasonló számú vállalkozás folytat ingatlanügyletekkel kapcsolatos, valamint pénzügyi, illetve biztosítási tevékenységet.

A cégek pénzügyi adatainak főbb leíró statisztikáját a 2. táblázatban mutatjuk be. A mintában szereplő nem tőzsdei cégek tőkearányos jövedelmezősége 2014-ről 2015re jelentős mértékben csökkent. ${ }^{18}$ A tőzsdei cégek esetében a jövedelmezőség kisebb mértékű javulása figyelhető meg. Méretük lényegesen nagyobb, mind az árbevétel, mind a saját tőke, mind az eszközállomány tekintetében. Fontos kiemelni, hogy mind a jegyzett, mind a tőzsdén kívüli cégek esetében a vizsgált mutatók kismértékü csök-

\footnotetext{
${ }^{18}$ A mintában szereplő nem tőzsdei cégek adatait https://bit.ly/2PkCXT9 internetcímen közöljük.
} 


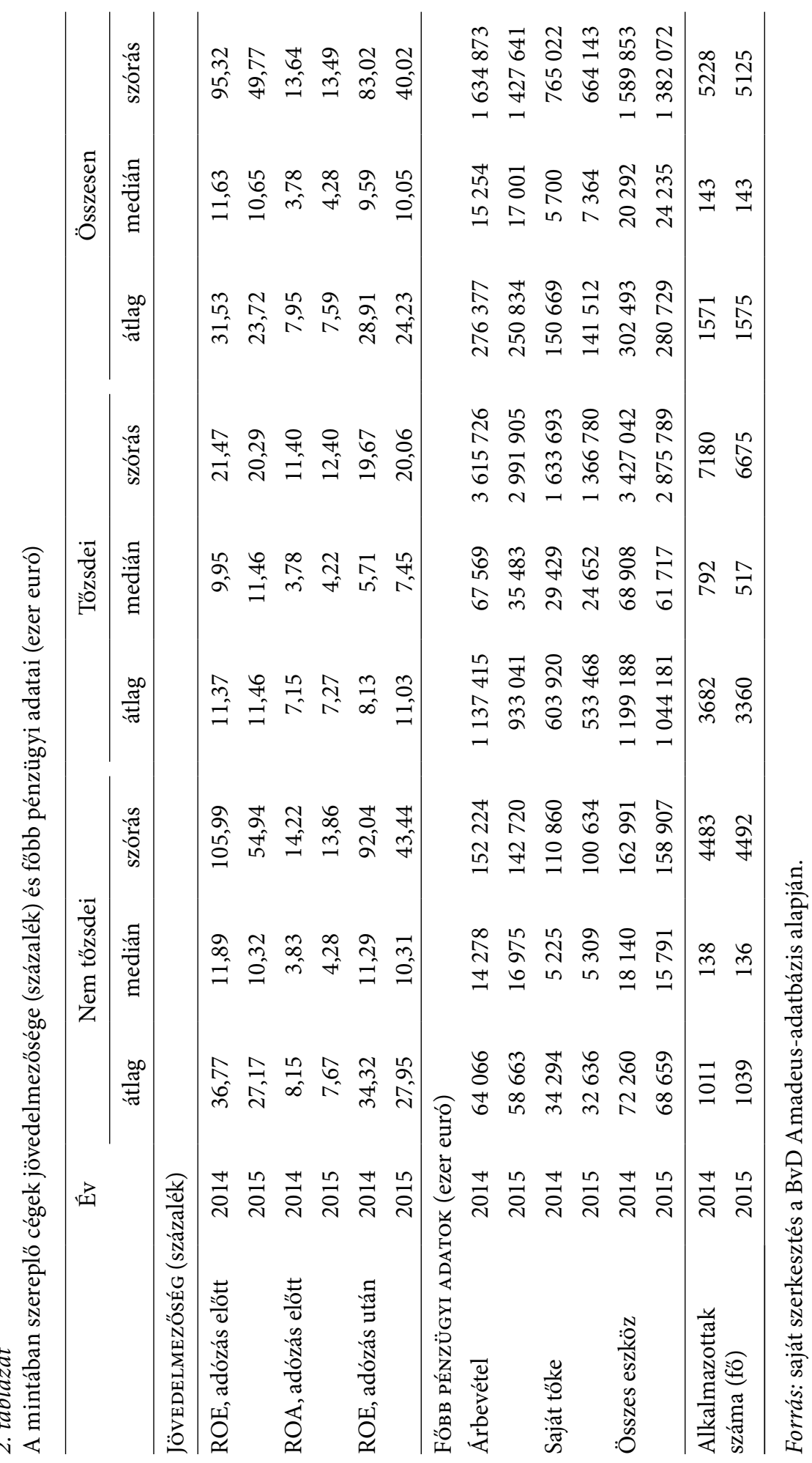


kenése figyelhető meg (eszközállomány, árbevétel, munkavállalók száma, saját tőke). Ezt a tőzsdén kívüli cégek esetében elsősorban az építőipar, a bányászat, valamint a távhőcégek, míg a tőzsdén kereskedett vállalkozások esetében a pénzügyi, illetve biztosítási cégek teljesítménye okozta.

A mintában szereplő 95 cég közül fenntarthatósági beszámolót csupán 8 (8,4 százalék) tett közzé, ebből 4 a tőzsdén jegyzett. Az eredmény nem konzisztens a KPMG [2010] felmérésével, amit az okozhat, hogy a mintában szereplö cégek véletlenszerüen kiválasztott nagyvállalatok, míg a KPMG kutatásában a 100 legjelentősebb hazai vállalat szerepelt. Feltételezhető, hogy a minta nagyobb vállalatokra való korlátozása esetén a fenntarthatósági beszámolóval érintett cégek aránya magasabb lenne.

Az ISO 9001 szabványt a mintában szereplő cégek körülbelül harmada (32,6 százalék) alkalmazta. Kiemelendő, hogy a nem tőzsdei cégek 37,3 százaléka, míg a várakozásokkal ellentétben a tőzsdei cégeknek csupán 15 százaléka rendelkezik ezzel a tanúsítvánnyal. Az ISO 14001 vagy az OHSAS 18001 közül az egyikkel a mintában szereplő vállalatok 28,4 százaléka rendelkezik. E tekintetben nincs jelentős eltérés a tőzsdei és a nem tőzsdei cégek jellemzői között. Az ISO 9001 mellett az ISO 14001 vagy az OHSAS 18001 szabvány együttes alkalmazása a cégek ötödénél figyelhető meg. ${ }^{19}$ Bár ezek az értékek, főleg a külföldi tapasztalatok tükrében, alacsonynak tünhetnek, Géring [2015] kutatási eredményei alapján a magyarországi közép- és nagyvállalatok társadalmi felelősségvállalásának kommunikációját jelentős mértékben áthatja a külső hitelesítésre való hivatkozás.

\section{A pénzügyi és nem pénzügyi teljesitmény közötti kapcsolat vizsgálata}

A különböző indikátorok alapján fenntarthatónak minősített, illetve az ilyen indikátorokkal nem rendelkező cégek pénzügyi mutatóinak azonosságát kétszélü Wilcoxon-próbával elemeztük (3. táblázat). Az elemzés alapján megállapítható, hogy az összevont fenntarthatósági indikátor alapján fenntarthatónak ítélt vállalkozások eszközarányos megtérülésének (ROA) mediánja szignifikánsan eltér a nem fenntarthatókétól $(p=0,002)$. Ez az eredmény azonban csak a mintában szereplő nem tőzsdei cégekre jellemző $(p=0,002)$, a tőzsdei cégek esetében a fenntartható és a nem fenntartható cégek jövedelmezőségének mediánja azonosnak tekinthető $(p=0,499)$. A fenntarthatósági indikátorok egyedi elemzése alapján megállapítható, hogy a medián eltérését elsősorban az ISO 9001 tanúsítvány megléte okozza $(p=0,016$ a teljes mintában, míg $p=0,006$ a nem tőzsdei cégek esetén). Befolyásoló tényező lehet

\footnotetext{
${ }^{19}$ Összehasonlításként a Witjes és szerzőtársai [2017] által vizsgált 18 holland kis- és középvállalkozás közül mindegyik alkalmazott ISO 9001 szabványt, míg az ISO 14001 és az OHSAS 18001 szabványt rendre 56-56 százalékuk. Ezt az eltérést három tényező is magyarázhatja: 1. a holland gazdaság sokkal közelebb áll az amerikai típusú, liberális modellhez, mint a kontinentális európaihoz; 2 . Witjes és szerzőtársai [2017] olyan vállalkozásokból álló mintát alkalmazott, mely explicit igényt fogalmazott meg a működés fenntarthatóbbá tétele irányában; 3. a holland társadalom (fejlettségéből adódóan) erősebb igényt támaszt a felelös vállalati működésre.
} 
még az ISO 14001 vagy az OHSAS 18001 szabványok legalább egyikének megléte $(p=0,081)$, de az indikátor hatása egyik almintán sem szignifikáns.

\section{3. táblázat}

A fenntarthatósági beszámolók szerinti jövedelmezőségi vizsgálat kétszélű Wilcoxon-próbával

\begin{tabular}{|c|c|c|c|c|c|c|}
\hline & \multicolumn{2}{|c|}{ Teljes minta } & \multicolumn{2}{|c|}{ Nem tőzsdei } & \multicolumn{2}{|c|}{ Tözsdei } \\
\hline & $W$ & p-érték & $W$ & p-érték & $W$ & $p$-érték \\
\hline \multicolumn{7}{|l|}{ FENNTARTHATÓSÁG } \\
\hline ROE, adózás előtt & 3519 & $0,104^{+}$ & 2282 & 0,243 & 130 & 0,343 \\
\hline ROA, adózás előtt & 3067,5 & $0,002^{*}$ & 1866 & $0,002^{*}$ & 139 & 0,499 \\
\hline ROE, adózás után & 3513 & $0,101^{+}$ & 2305 & 0,282 & 130 & 0,343 \\
\hline \multicolumn{7}{|c|}{ FENNTARTHATÓSÁGI BESZÁMOLÓ } \\
\hline ROE, adózás előtt & 1421 & 0,676 & 493 & 0,66 & 144 & 0,505 \\
\hline ROA, adózás előtt & 1325 & 0,897 & 415 & 0,241 & 151 & 0,364 \\
\hline ROE, adózás után & 1511 & 0,389 & 535 & 0,941 & 139 & 0,621 \\
\hline \multicolumn{7}{|l|}{ ISO 9001} \\
\hline ROE, adózás előtt & 3277 & 0,22 & 2155 & 0,257 & 108 & 0,747 \\
\hline ROA, adózás előtt & 2924,5 & $0,016^{*}$ & 1805 & $0,006^{*}$ & 106 & 0,805 \\
\hline ROE, adózás előtt & 3177 & 0,128 & 2114 & 0,193 & 108 & 0,747 \\
\hline \multicolumn{7}{|c|}{ ISO 9001 És ISO 14001 VAGY OHSAS 18001} \\
\hline ROE, adózás előtt & 2693 & 0,832 & 1726 & 0,753 & 108 & 0,747 \\
\hline ROA, adózás előtt & 2492 & 0,307 & 1563 & 0,218 & 106 & 0,805 \\
\hline ROE, adózás után & 2575 & 0,537 & 1639 & 0,464 & 108 & 0,747 \\
\hline \multicolumn{7}{|c|}{ ISO 14001 VAGY OHSAS 18001} \\
\hline ROE, adózás előtt & 3243 & 0,464 & 2048 & 0,681 & 130 & 0,343 \\
\hline ROA, adózás előtt & 2959 & $0,081^{\star *}$ & 1833 & 0,13 & 139 & 0,499 \\
\hline ROE, adózás után & 3210 & 0,404 & 2006 & 0,552 & 130 & 0,343 \\
\hline
\end{tabular}

** 5 százalékos, ${ }^{*} 10$ százalékos, ${ }^{+}$korlátozásokkal 10 százalékos szignifikanciaszinten szignifikáns változók.

Forrás: saját számítás.

Kiemelendő, hogy az összevont fenntarthatósági indikátor alapján a fenntartható és a nem fenntartható cégek jövedelmezőségének mediánja az adózás előtti és az adózás utáni ROE esetében eltérhet (a p értéke rendre 0,104 illetve 0,101), de ez az eltérés a részletesebb indikátorok vizsgálata esetén nem szignifikáns.

A fenntartható, illetve a nem fenntartható cégek jövedelmezősége közötti különbséget egyszélü Wilcoxon-próbával elemeztük (4. táblázat). Az összevont fenntarthatósági indikátor alapján fenntarthatónak tekinthető vállalkozások megtérülése mind a három vizsgált jövedelmezőségi mutató alapján szignifikánsan magasabb. Az indikátor a legnagyobb hatást az eszközarányos megtérülésre (ROA) gyakorolja $(p=0,001)$. 
A ROA nagyságát az ISO 9001 szabvány megléte $(p=0,008)$, illetve az ISO 14001 vagy az OHSAS 18001 szabványok legalább egyikének megléte $(p=0,041)$ okozza. Az indikátorok csak a nem tőzsdei cégekre vonatkozó almintában szignifikánsak.

Bár az összevont fenntarthatósági indikátor mindkét ROE-mutatóra szignifikáns hatást gyakorol ( $p=0,052$ az adózási előtti, $p=0,05$ az adózás utáni bázison számítottra), a hatás egyik almintán sem jelentkezik. Ki kell emelnünk, hogy a teljes mintán az ISO 9001 szabvány megléte esetén az adózás utáni bázison számított ROE-mutató szignifikánsan magasabb $(p=0,064)$, ami a nem tőzsdei almintán is jelentkezik $(p=0,096)$. Megállapítható továbbá, hogy az elemzésben nem szerepel olyan, a fenntarthatósággal kapcsolatos indikátor, amely a jövedelmezőség szignifikáns csökkenésével járna együtt.

4. táblázat

A fenntarthatósági beszámolók szerinti jövedelmezőségi vizsgálat egyszélü Wilcoxon-próbával

\begin{tabular}{|c|c|c|c|c|c|c|}
\hline & \multicolumn{2}{|c|}{ Teljes minta } & \multicolumn{2}{|c|}{ Nem tőzsdei } & \multicolumn{2}{|c|}{ Tőzsdei } \\
\hline & $W$ & p-érték & $W$ & p-érték & $W$ & p-érték \\
\hline \multicolumn{7}{|l|}{ FenNTARThatósÁg } \\
\hline ROE, adózás előtt & 3519 & $0,052^{* *}$ & 2282 & 0,121 & 130 & 0,171 \\
\hline ROA, adózás előtt & 3068 & $0,001^{*}$ & 1866 & $0,001^{*}$ & 139 & 0,249 \\
\hline ROE, adózás után & 3513 & $0,050^{* *}$ & 2305 & 0,141 & 130 & 0,171 \\
\hline \multicolumn{7}{|c|}{ FENNTARTHATÓsÁGI BESZÁMOLÓ } \\
\hline ROE, adózás előtt & 1421 & 0,664 & 493 & 0,330 & 144 & 0,758 \\
\hline ROA, adózás előtt & 1325 & 0,449 & 415 & 0,120 & 151 & 0,827 \\
\hline ROE, adózás után & 1511 & 0,807 & 535 & 0,471 & 139 & 0,702 \\
\hline \multicolumn{7}{|l|}{ ISO 9001} \\
\hline ROE, adózás előtt & 3277 & 0,11 & 2155 & 0,129 & 108 & 0,641 \\
\hline ROA, adózás előtt & 2925 & $0,008^{*}$ & 1805 & $0,003^{*}$ & 106 & 0,612 \\
\hline ROE, adózás előtt & 3177 & $0,064^{* *}$ & 2114 & $0,096^{* *}$ & 108 & 0,641 \\
\hline \multicolumn{7}{|c|}{ ISO 9001 És ISO 14001 VAGY OHSAS 18001} \\
\hline ROE, adózás előtt & 2693 & 0,416 & 1726 & 0,377 & 108 & 0,641 \\
\hline ROA, adózás előtt & 2492 & 0,154 & 1563 & 0,109 & 106 & 0,612 \\
\hline ROE, adózás után & 2575 & 0,268 & 1639 & 0,232 & 108 & 0,641 \\
\hline \multicolumn{7}{|c|}{ ISO 14001 VAGY OHSAS 18001} \\
\hline ROE, adózás előtt & 3243 & 0,232 & 2048 & 0,341 & 130 & 0,171 \\
\hline ROA, adózás előtt & 2959 & $0,041^{*}$ & 1833 & $0,065^{\star *}$ & 139 & 0,249 \\
\hline ROE, adózás után & 3210 & 0,202 & 2006 & 0,276 & 130 & 0,171 \\
\hline
\end{tabular}

** 5 százalékos, ${ }^{\star} 10$ százalékos szignifikanciaszinten szignifikáns változók. A kétszélű teszten szignifikáns változók dőlten szedve.

Forrás: saját számítás. 


\section{Következtetések}

Az elemzések alapján a tőzsdei cégek fenntarthatósági gyakorlata és jövedelmezősége között nem mutatható ki szignifikáns kapcsolat. A nem tőzsdei cégeknél igazolható, hogy az ISO 9001 tanúsítvány, valamint az ISO 14001 vagy az OHSAS 18001 tanúsítványok legalább egyikének megléte szignifikáns pozitív hatást gyakorol az eszközarányos megtérülésre. Az ISO 9001 tanúsítvánnyal rendelkező nem tőzsdei cégek adózás utáni ROE-mutatója szintén szignifikánsan magasabb, mint a tanúsítvánnyal nem rendelkező cégeké.

A különböző tanúsítványok jelentős szerepe konzisztens Géring [2015] eredményeivel, miszerint a magyarországi közép- és nagyvállalatok társadalmi felelősségvállalásának kommunikációja elsősorban a külső hitelesítésre támaszkodik.

A tanulmányban feltárt eredmények konzisztensek az Earnhart-Lizal [2007] cseh, illetve a Przychodzen-Przychodzen [2015] cseh és magyar vállalatokat érintő tanulmányában szereplő megállapításokkal, azaz a magyarországi cégek teljesítménye elsősorban a visegrádi országokhoz konvergál, ellentétben Pintea és szerzőtársai [2014] romániai mintán alapuló megállapításaival.

A fenntarthatósági beszámolók alkalmazásának alacsony aránya, valamint az elsősorban különbözö tanúsítványokon alapuló társadalmi felelősségvállalás a felelősségvállalás alacsony szintjét jelöli. Ez összhangban van a Dunphyés szerzőtársai [2006] (idézi Witjes és szerzőtársai [2017]) által kifejtett, fenntarthatósággal kapcsolatos attitüdváltozás hat lépcsőjével. Eszerint a vállalkozások 1. eleinte elutasítják a felelős müködést, később ezt 2. közöny váltja fel, majd teret nyer 3. a különböző szabványoknak, külső elvárásoknak való megfelelés. Ezt követi 4. a hatékonyság növelése, 5. a stratégiai proaktivitás, majd végül 6 . a fenntartható müködés. Az elemzés eredményei alapján feltételezhető, hogy a Magyarországon aktív nagyvállalatok a 2. és a 3. szakasz között helyezkednek el.

Ez a köztes helyzet arra enged következtetni, hogy történt ugyan fejlődés, de a magyar társadalom számára továbbra is nagyobb értéket jelent a gazdasági növekedés, vagyis a nyugat-európai életszínvonalhoz való felzárkózás, mint a társadalmi vagy a környezeti teljesítmény. Ez konzisztens Losoncz [2017] eredményeivel, amely szerint a régióban 2007 és 2016 között Lengyelországban volt mérhetö a legnagyobb mértékủ gazdasági növekedés az egy főre jutó GDP tekintetében, Csehország pedig ugyanezen időszakban csaknem felzárkózott az EU28 átlagához. Magyarország gazdasági teljesítménye viszont az EU28 60 százalékáról mindössze 67 százalékára növekedve csekély mértékủ emelkedést produkált.

\section{Összefoglalás}

A nagyvállalkozások gyakorlatában egyre nagyobb szerepet kap a tevékenységük társadalmi hatásaiért való felelősségvállalás (CSR). Ez nem feltétlenül önkéntesen vállalt kötelezettség, mert egyrészt a jogi környezet elöírásai, másrészt a társadalom informális intézményei egyaránt kikényszeríthetik. A társadalmi felelősségvállalás elsősorban a fejlett világ országaiban bevett gyakorlat, a fejlődő és a felzárkózó országok vállalkozásai az intézményesülés különböző periódusaiban vannak. 
Az Európai Unió kelet-közép-európai tagállamai különleges helyzetben vannak, ugyanis párhuzamosan él együtt a szocialista múlt „CSR-öröksége” (Kerekes-Wetzker [2007]), a multinacionális vállalatok helyi leányvállalatai által alkalmazott legjobb gyakorlatokkal kapcsolatos szkepszis (Radácsi [2011]), valamint az Európai Unió környezetvédelemmel és társadalommal kapcsolatos jogalkotása és támogatási programjai.

Jelen tanulmányban a Magyarországon működő nagyvállalatok pénzügyi és nem pénzügyi teljesítménye közötti összefüggést vizsgáltuk. Az elemzést 95, véletlenszerüen kiválasztott cég 2014. és 2015. évi pénzügyi adatai alapján végeztük el. A kiválasztási arány az egyes vállalattípusok között nem egyenlő: a Budapesti Értéktőzsde prémiumrészvényei esetén a mintavételi arány 78,6 százalék (11 cég), míg a standard részvények körében 46,7 százalék ( 9 cég). A mintában 75 tőzsdén nem jegyzett nagyvállalat szerepel, melyek a székhely régiója szerint arányosan kerültek kiválasztásra.

Az elemzések alapján megállapítható, hogy a fenntarthatósággal kapcsolatos indikátorok csak a nem tőzsdei cégek jövedelmezőségére gyakorolnak szignifikáns hatást. Az ISO 9001 szabvány megléte szignifikáns pozitív hatást gyakorol az adózás előtti bázison számított eszközarányos megtérülésre (ROA), továbbá az adózás utáni bázison számított tőkearányos jövedelmezőségre (ROE). Ezenkívül az ISO 14001 vagy az OHSAS 18001 szabványok legalább egyikével rendelkező vállalkozások esetén szignifikánsan magasabb ROA-mutató várható. A tanulmány következtetései illeszkednek Earnhart-Lizal [2007] cseh, illetve Przychodzen-Przychodzen [2015] cseh és magyar vállalatokat tartalmazó mintán végzett elemzéséhez. Ez azt jelenti, hogy a magyarországi vállalatok esetében is bizonyítható a pénzügyi és a nem pénzügyi teljesítmény közötti szignifikáns pozitív kapcsolat.

Az elemzés alapjául szolgáló minta elemszáma alacsony, így torzítások a véletlenszerű kiválasztás mellett is lehetségesek. A fenntarthatósági beszámolók elsődleges forrása a Corporate Register, ahol számos vállalat adatai megtalálhatók, Magyarországról az érdeklődés mértéke azonban meglehetősen csekély (2012-ben 28, míg 2016-ban csupán 19 szervezet évi fenntarthatósági beszámolója került fel). Ennek megfelelően a fenntarthatósági beszámolók közzétételét és a szabványok meglétét kiegészítettük a vállalkozások saját weboldalain található információk alapján, ami bizonytalanságokat hordoz.

További kutatási irányként jelölhető meg egyrészt az eredmények nagyobb mintán, több változó bevonásával történő validálása, másrészt a hazai kis- és középvállalati szektor magatartásának kvalitatív, illetve kvantitatív módszerekkel történő vizsgálata.

\section{Hivatkozások}

Angelia, D.-Suryaningsih, R. [2015]: The Effect of Environmental Performance And Corporate Social Responsibility Disclosure Towards Financial Performance (Case Study to Manufacture, Infrastructure, And Service Companies That Listed At Indonesia Stock Exchange). Procedia - Social and Behavioural Sciences, Vol. 411. 348-355. o. https://doi. org/10.1016/j.sbspro.2015.11.045. 
Blasi, S.-CAporin, M.-Fontini, F. [2018]: A multidimensional analysis of the relationship between corporate social responsibility and firms' economic performance. Ecological Economics, Vol. 147. 218-229. o. https://doi.org/10.1016/j.ecolecon.2018.01.014.

BRAUn RóBERT [2013]: A vállalatok politikája - vállalati, társadalmi felelősségvállalás, vállalati közösségek és a vállalati stratégia jövője. Vezetéstudomány, 44. évf. 1. sz. 18-28. o.

Brine, M.-Brown, R.-Hackett, G. [2007]: Corporate Social Responsibility and Financial Performance in the Australian Context. Economic Round-up, őszi szám, 47-58. o.

Carroll, A. B. [1979]: A Three-Dimensional Conceptual Model of Corporate Social Performance. Academy of Management Review, Vol. 4. No. 4. 497-505. o.

CARroll, A. B. [1991]: The pyramid of corporate social responsibility: Toward the moral management of organizational stakeholders. Business Horizons, Vol. 34. No. 4. 39-48.o. https://doi.org/10.1016/0007-6813(91)90005-g.

Cheng, B.-Ioannou, I-Serafeim, G. [2011]: Corporate Social Responsibility and Access to Finance. Strategic. Management Journal, Vol. 35. No. 1. 1-23. o. http://dx.doi.org/10.2139/ ssrn. 1847085.

Crifo, P.-Diaye, M.-Pekovic, S. [2016]: CSR related management practices and firm performance. An empirical analysis of the quantity-quality trade-off on French data. International Journal of Production Economics, Vol. 171. 405-416. o. http://dx.doi.org/10.1016/j. ijpe.2014.12.019.

Csizmadia Edit-Vaszkó Csaba [2016]: A legnagyobb magyar vállalatok éghajlatvédelemmel kapcsolatos elkötelezettségének és vállalásainak vizsgálata. A TOP 50 az értékesítés nettó átbevétele alapján. WWF Magyarország, http://wwf.hu/media/file/1463064951_ wwf_kutatasi_osszefoglalo_2016_04.pdf.

Dhaliwal, D.-Radhakrishnan, S.-Tsang, A.-Yang, Y. G. [2012]: Nonfinancial Disclosure and Analyst Forecast Accuracy. International Evidence on Corporate Social Responsibility Disclosure. Accounting Review, Vol. 87. No. 3. 723-759. o. https:/doi.org/ 10.2308/accr-10218.

Dunphy, D.-Griffiths, A.-BEnN, S. [2006]: Organizational Change for Corporate Sustainability: a Guide for Leaders and Change Agents of the Future. Organizational Change for Corporate Sustainability. Routledge, New York City.

EARnhart, D.-Lizal, L. [2007]: Does better environmental performance affect revenues, cost, or both? Evidence from a transition economy. William Davidson Institute, Working Paper, No. 856.

EB [2011]: A Bizottság közleménye az Európai Parlamentnek, a Tanácsnak, a Gazdasági és Szociális Bizottságnak és a Régiók Bizottságának. A vállalati társadalmi felelősségvállalásra vonatkozó megújult uniós stratégia (2011-2014). Európai Bizottság, COM/2011/0681. http://eur-lex.europa.eu/legal-content/HU/TXT/?uri=CELEX\%3A52011DC0681.

Farkas Szilveszter-Szigeti Cecília [2011]: Alternative indicators of sustainability and social responsibility. Bulletin of the Kyiv National University of Technology and Design, Vol. 5. 192-197. o.

FrIEDMAN, M. [1970]: The social responsibility of business is to increase its profits. The New York Times Magazine, szeptember 13. https:/www.nytimes.com/1970/09/13/archives/afriedman-doctrine-the-social-responsibility-of-business-is-to.html.

GÉRING ZsuzsanNa [2015]: A vállalati társadalmi felelősségvállalás online vállalati diskurzusa. Avagy mit és hogyan kommunikálnak a hazai közép- és nagyvállalatok honlapjaikon a társadalmi szerepükről és felelősségükről. Doktori értekezés. https://doi.org/10.14267/ phd.2015061. 
Ghoul, S. E.-Guedhami, O.-Kwok, C. C. Y.-Mishra, D. R. [2011]: Does corporate social responsibility affect the cost of capital? Journal of Banking and Finance, Vol. 35. No. 9. 2388-2406. o. https://doi.org/10.1016/j.jbankfin.2011.02.007.

Heinkel, R.-Kraus, A.-Zechner, J. [2001]: The Effect of Green Investment on Corporate Behavior. Journal of Financial and Quantitative Analysis, Vol. 36. No. 4. 431-449. o. https:// doi.org/10.2307/2676219.

KEREKES SÁNDOR-WETZKer KonRÁD [2007]: Keletre tart a „társadalmilag felelős vállalat” koncepció. Harvard Business Manager (magyar kiadás), 9. évf. 4. sz. 37-47. o.

KPMG [2010]: Felelősségvállalás és fenntarthatóság a magyarországi nagyvállalatoknál. A 2008-2009-es jelentések tükrében. KPMG Tanácsadó Kft., http://www.brandtrend.hu/ musor/kpmg_csr_jelentesek_2010.pdf.

KuTi MóNıKa [2014]: A fenntarthatóság és a pénzügyek integrálhatóságának kihívásai. Hitelintézeti Szemle, 13. évf. 2. sz. 164-173. o.

LI, M.-ZÉMAn ZoLtáN-LI, J. [2016]: A vállalatok társadalmi felelősségvállalásának hatása a kínai gazdasági fejlődésre. Pénzügyi Szemle, 64. évf. 4. sz. 512-527. o.

Losoncz MikLós [2017]: A globális és regionális integrálódás és a fenntartható gazdasági növekedés néhány kérdése a visegrádi országokban. Közgazdasági Szemle, 64. évf. 7-8. sz. 677-697. o. http://dx.doi.org/10.18414/KSZ.2017.7-8.677.

Margolis, J. D.-Elfenbein, H. A.-Walsh, J. P. [2009]: Does it Pay to Be Good... And Does it Matter? A Meta-Analysis of the Relationship between Corporate Social and Financial Performance. http://dx.doi.org/10.2139/ssrn.1866371.

Mathuva, D. M.-Kiweu, J. M. [2016]: Cooperative social and environmental disclosure and financial performance of savings and credit cooperatives in Kenya. Advances in Accounting, Incorporating Advances in International Accounting, Vol. 35. 197-206 o. http://dx.doi. org/10.1016/j.adiac.2016.09.002.

Ng, A. C.-Rezaee, Z. [2015]: Business sustainability performance and cost of equity capital. Journal of Corporate Finance, Vol. 34. 128-149 o. https://doi.org/10.1016/j. jcorpfin.2015.08.003.

Orlitzky, M.-Benjamin, J. D. [2011]: Corporate Social Performance and Firm Risk. A Meta-Analytic Review. Business and Society, Vol. 40. No. 4. 369-396. o. https://doi. org/10.1177/000765030104000402.

ÖzçELIK, F.-AvCi Öztürk, B.-GursakaL, S. [2014]: Investigating the relationship between corporate social responsibility and financial performance in Turkey. Ataturk University Journal of Economics and Administrative Sciences, Vol. 28. No. 3. 189-203. o.

Pintea, M. O.-Stanca, L.-Achim, S. A.-Pop, I. [2014]: Is There a Connection Among Environmental and Financial Performance of a Company in Developing Countries? Evidence from Romania. Procedia Economics and Finance, Vol. 15. 822-829. o. https://doi. org/10.1016/S2212-5671(14)00527-9.

Przychodzen, J.-Przychodzen, W. [2015]: Relationships between eco-innovation and financial performance - evidence from publicly traded companies in Poland and Hungary. Journal of Cleaner Production, Vol. 90. 253-263 o. https://doi.org/10.1016/j.jclepro. 2014.11.034.

RAdácsi LÁszló [2011]: A közép-európai CSR paradoxon. Harvard Business Review (magyar kiadás), 13. évf. 12. sz. 28-39. o.

SIEW, R. Y. J. [2015]: A review of corporate sustainability reporting tools (SRTs). Journal of Environmental Management, Vol. 164. 180-195. o. http://dx.doi.org/10.1016/j. jenvman.2015.09.010. 
ŠKare, M.-GolJA, T. [2012]: Corporate social responsibility and financial performance: is there a link? Economic research - Ekonomska istraživanja, Vol. 25. No. 1. 215-242 o.

Stanwick, P. A.-Stanwick, S. D. [1998]: The Relationship Between Corporate Social Performance, and Organizational Size, Financial Performance, and Environmental Performance: An Empirical Examination. Journal of Business Ethics, Vol. 17. No. 2. 195-204. o. https:// doi.org/10.1023/A:1005784421547.

SzÉKely FerenC-KNirsch, M. [2005]: Responsible Leadership and Corporate Social Responsibility: Metrics for Sustainable Performance. European Management Journal, Vol. 23. No. 6. 628-647. o. https://doi.org/10.1016/j.emj.2005.10.009.

Szennay Áron [2016]: Possibilities of corporate financial and non-financial performance measurement. Journal of Financial Management and Accounting, Vol. 4. No. 2. 59-69. o.

Tomšıč, N.-Bojnec, Š.-SimČıč, B. [2015]: Corporate sustainability and economic performance in small and medium sized enterprises. Journal of Cleaner Production, Vol. 108. 603-612. o. https://doi.org/10.1016/j.jclepro.2015.08.106.

Tsoutsoura, M. [2004]: Corporate Social Responsibility and Financial Performance. Center for Responsible Business. UC Berkeley: Center for Responsible Business. http://escholarship. org/uc/item/111799p2.

Witjes, S.-WAlter, J. V.-Cramer, M. [2017]: Exploring corporate sustainability integration into business activities. Experiences from 18 small and medium sized enterprises in the Netherlands. Journal of Cleaner Production, Vol. 153. 528-538. o. https://doi.org/10.1016/j. jclepro.2016.02.027.

\section{Kedves Szerzőink!}

Az MTA Könyvtár és Információs Központtal együttműködve cikkeinket ellátjuk a CrossRef-nél regisztrált DOI-azonosítóval. Ezért kérjük, hogy a Hivatkozásokban tüntessék fel a művek DOl-azonosítóját (természetesen sokszor előfordul, hogy nincs ilyen). A DOI a következő linkre kattintva kereshető meg: http://search.crossref.org.

Például:

Boldrin, M.-Montes, A. [2005]: The intergenerational state. Education and pensions. Review of Economic Studies, Vol. 72. No. 3. 651-664. o.

A hivatkozott tételt bemásoljuk a keresőmezőbe, a találati listából pedig kiválasztjuk a megfelelő tételnél lévő hivatkozást, és beszúrjuk a hivatkozás végére: BoldRIN, M.-Montes, A. [2005]: The intergenerational state. Education and pensions. Review of Economic Studies, Vol. 72. No. 3.651-664. o. http://dx.doi.org/10. 1111/j.1467-937x.2005.00346.x.

Ne feledkezzenek meg a beszúrt hivatkozás hiperhivatkozásként való megjelöléséről a kéziratban!

A CrossRef-nél regisztrált DOI növeli a cikkek láthatóságát, könnyíti az adott, kapott hivatkozások összeszámlálását! 